\title{
UNESCO-KU-ICL UNITWIN Cooperation Programme for Landslides and Water-Related Disaster Risk Management
}

\author{
Kaoru Takara and Kyoji Sassa
}

\begin{abstract}
UNITWIN is the abbreviation for the university twinning and networking scheme. This UNESCO programme was established in 1992. During ICL foundation meeting in January 2002, participants from UNESCO advised to link the planned International Programme on Landslides (IPL) to one of UNESCO Programme for the promotion and the authorization. Then, ICL applied for UNITWIN programme to UNESCO soon after the foundation of ICL in 2002. UNITWIN-UNESCO/KU/ICL Landslides Mitigation for Society and Environment Cooperation Programme was established in 2003 at Kyoto University, Kyoto, Japan. In 2010, the UNESCO-KU-ICL UNITWIN Cooperation Programme was extended to "Landslide and Water-Related Disaster Risk Management" to include more participants dealing with rainfall-induced landslides on slopes, as well as flood, sediment and debris flows in river systems. This paper describes its progress and the activities of capacity development including the list of students and post-doctoral researchers within this programme.
\end{abstract}

\section{Keywords}

UNESCO • UNITWIN programme - International programme on landslides (IPL) • International consortium on landslides (ICL) - Kyoto university

\section{Introduction}

During the International Decade for Natural Disaster Reduction (IDNDR) (1990-1999), which was a UN-designated decade for promotion of disaster prevention and mitigation activities, the Disaster Prevention Research Institute (DPRI) of Kyoto University conducted a number of international cooperative research projects with Asian countries such as China, Indonesia and the Philippines. One of them was a research project on the Lishan Landslide in $\mathrm{Xi}$ 'an, China, to assess the landslide hazard and protect a cultural heritage site, the Lishan Resort Palace from the Tan Dynasty (618-907), located at the foot of Lishan Slope. No landslide has occurred in this slope since the Tan Dynasty, but landslide experts in Japan and China indicated the necessity of detailed monitoring and testing, by mobilizing the most advanced technologies and establishing new landslide hazard assessment technology to protect this cultural

\section{K. Sassa}

UNITWIN Cooperation Programme from ICL,

Kyoto University, Kyoto, Japan

e-mail: sassa@iclhq.org

K. Sassa

International Consortium on Landslides, 138-1 Tanaka-Asukai Cho, Sakyo-Ku, Kyoto, 606-8226, Japan 
heritage. Based on the results of this Japan-China joint research, in parallel, UNESCO-IUGS Joint Programme IGCP (International Geological Correlation Programme) sought the development of IGCP from "Geological Correlation" to "Geoscience for the Society". Our project was evaluated to be a good example of "Geoscience for the Society". This project was submitted to IGCP, and IGCP-425: "Landslide Hazard Assessment and Cultural Heritage" (1998-2004) was approved. Note that it is renamed as the International Geoscience Programme but still keeps its original abbreviation IGCP; currently it is a part of the International Geoscience and Geoparks Programme (IGGP), which was approved officially on 17 November 2015 at the General Conference of UNESCO.

As a part of the activities of IGCP-425, the DPRI, Kyoto University (KU), organized a UNESCO-Kyoto University Joint Symposium in Kyoto, Japan in 2002, which included participants from UNESCO, UNISDR, WMO, and Japanese ministries such as MOFA (Ministry of Foreign Affairs) and MEXT (Ministry of Education, Culture, Sports, Science and Technology). At this occasion, the International Consortium on Landslides was officially established and UNESCO proposed the establishment of a UNESCO-KU-ICL UNITWIN Network to support the International Programme on Landslides (IPL), which is considered a scientific programme contributing to UNISDR. This manuscript outlines the development of the UNESCO-KU-ICL UNITWIN Network since its official establishment in March 2003.

\section{UNESCO UNITWIN Programme}

The UNITWIN programme is explained in the UNITWIN-UNESCO-Chair Programme WEB at: http://en. unesco.org/unitwin-unesco-chairs-programme as follows:

"UNITWIN" is the abbreviation for the university twinning and networking scheme. This UNESCO programme was established in 1992, in accordance with a resolution adopted by the General Conference of UNESCO at its 26th session (1991). The UNITWIN/UNESCO Chairs Programme consists of the establishment of UNESCO Chairs and UNITWIN Networks in higher education institutions. This UNESCO programme serves as a prime means of building the capacities of higher education and research institutions through the exchange of knowledge and sharing, in a spirit of international solidarity. Thus it promotes North-South, South-South and triangular cooperation as a strategy to develop institutions. These institutions work in partnership with NGOs, foundations and public and private sector organizations and play an important role in the field of higher education. The UNITWIN/UNESCO Chairs Programme opens avenues for the higher education and research community to join forces with UNESCO to contribute to the implementation of its programme and the achievement of the Millennium Development Goals (MDGs). The UNITWIN/UNESCO Chairs Programme covers training, research and exchange of academics and offers a platform for information sharing in all fields within the competence of UNESCO. The majority of the projects are interdisciplinary and intersectoral and involve all the programme sectors of UNESCO, with the active cooperation of its field Offices, Institutes and Centres. National Commissions play an important role by helping to promote the programme nationally, facilitating its execution and evaluating its impact. Because it is totally multidisciplinary in nature, the UNITWIN/UNESCO Chairs Programme is one of the Organization's most intersectoral programmes".

Currently 50 UNITWIN networks from 24 countries are ongoing as of 1st December 2016. UNITWIN Networks in the fields of Disaster Risk Reduction (only two) and sustainable development (six) are introduced below from the UNITWIN-UNESCO-Chair Programme WEB (many French titled networks are included, but they are not introduced here).

1. UNITWIN-UNESCO/KU/ICL International Consortium on Landslides Mitigation for Society and Environment Cooperation Programme (605), established in 2003 at Kyoto University, Kyoto, Japan

2. The Network on Emergency Preparedness and Responses (704), established in 2005 at Waseda University, Tokyo, Japan

3. UNESCO Interdisciplinary Chair/Network for Sustainable Development (6), established in 1995 at Universidad Católica de Cuyo, La Plata

4. UNESCO Chair/Network on Global Economics and Sustainable Development (42), established in 1996, Colegio do Brasil, Rio de Janeiro, RJ, Brasil.

5. UNESCO Chair/International Network of Water-Environment Centres for the Balkans on "Sustainable Management on Water and Conflict Resolution" (618), established in 2003 at the Aristotle University of Thessaloniki, Thessaloniki, Greece

6. Network on International Cooperation and Development (1114), established in 2015 at the University of Pavia and the University of Bethlehem University, Italy

7. International UNESCO Chair/Network on Transfer of Technologies for Sustainable Development (TTSD) (203), established in 1993 at the International Centre for Educational Systems, Moscow, Russia

8. UNITWIN Cooperation Programme in Marine Biology and Sustainable Development for East Africa (854), established in 2009 at the University of Dar-Es- Salaam and the Bangor University (U.K.), United Republic of Tanzania. 
Each UNITWIN cooperation programme has its own logo. Figure 1 is the logo of the UNESCO-KU-ICL UNITWIN Cooperation Programme.

\section{The First Phase of the UNESCO-KU-ICL UNITWIN Cooperation Programme}

In March 2003, the UNESCO-KU-ICL UNITWIN Network was agreed upon and signed at the Office of the President of Kyoto University among UNESCO, Kyoto University (KU) and ICL (Fig. 2); the name chosen for the network was the "Landslide Risk Mitigation for Society and the Environment Cooperation Programme." The joint network for landslide risk mitigation of UNESCO/KU/ICL is to carry out education, research and capacity building in the field of landslide risk mitigation. The activities are jointly conducted by Kyoto University (especially, the Research Centre on Landslides, which was established in 2003 in the Disaster Prevention Research Institute, and other groups in Kyoto University), ICL and ICL Supporting Organizations. The Integrated Disaster Risk Management group (NEXUS IDRiM), established in 2005 with its secretariat in DPRI, Kyoto University, has joined this network.

The UNESCO-KU-ICL UNITWIN Cooperation Programme was established in 2003 to be hosted in Kyoto University. The application to construct the UNITWIN headquarters building as its secretariat was approved by Kyoto University. ICL organized its international symposium on landslide risk mitigation and protection of cultural and natural heritage on 21-24 January in 2004. During this symposium, a memorial meeting of the establishment of the headquarters of UNESCO-KU-ICL UNITWIN Cooperation Programme was organized, inviting UNESCO, UNISDR, MEXT, Japan Meteorological Agency representing the WMO, and a representative from the Italian Embassy, as well as ICL members, in the main building of Kyoto University, together with President Kazuo Oike (bottom left photo of Fig. 3). The left panel of Fig. 3 is a symbol of the UNITWIN headquarters building. Prof. Oike composed a haiku- "Eyebrow moon in the sky of Andes, Realm of Landslides". The main IPL project at the beginning of ICL was "Landslides threatening World Heritage Machu Picchu, Peru". The background of this figure is the Machu Picchu citadel. The Andes Mountains are similar to the Japanese archipelago; both are affected by active faults and earthquakes and are full of landslides. All haiku include a key word symbolizing one of four seasons as a rule. Eyebrow moon is a key word of Autumn, and also symbolizes an initial stage of development to the full moon, with a wish for the development of ICL and IPL and UNITWIN. The panel is displayed in the UNITWIN headquarters building (top-right photo of Fig. 3). The building has three rooms, for joint research, the journal and a meeting room. The right-bottom photo presents the opening ceremony of UNITWIN Headquarters Building held in the central meeting room on 3 September 2004.

The President of Kyoto University (Dr. Kazuo Oike), three delegates from UNESCO (Dr. Wolfgang Eder, Director of the Division of Earth Sciences, Ms. Winsome Gordon, Section Head of Higher Education, Dr. Badaoui Rouhban, Section Head of Disaster Reduction), the Rector of UNU (Dr. Hans van Ginkel), officers from the Japanese Cabinet Office (Dr. Satoru Nishikawa) and the MEXT (Mr. Nakamura and Mr. Kasuo Akiyama), and the Peruvian Ambassador (Luis J. Macchiavello,), as well as DPRI colleagues, including Director at that time Kazuya Inoue, attended its opening ceremony (Fig. 3).

The ICL organized the 2006 Tokyo Round Table Discussion "Strengthening Research and Learning on Earth System Risk Analysis and Sustainable Disaster Management within UN-ISDR as Regards Landslides" towards a dynamic global network of the International Programme on Landslides (IPL) at the United Nations University (UNU), Tokyo, Japan on 18th to 20th January 2006. This international conference adopted the 2006 Tokyo Action Plan on the International Programme on Landslides (IPL). It proposed the global cooperation network of the IPL, and established the IPL Global Promotion Committee and the IPL World Centre as its secretariat to coordinate and support
Fig. 1 Logo of the UNESCO-KU-ICL UNITWIN cooperate programme

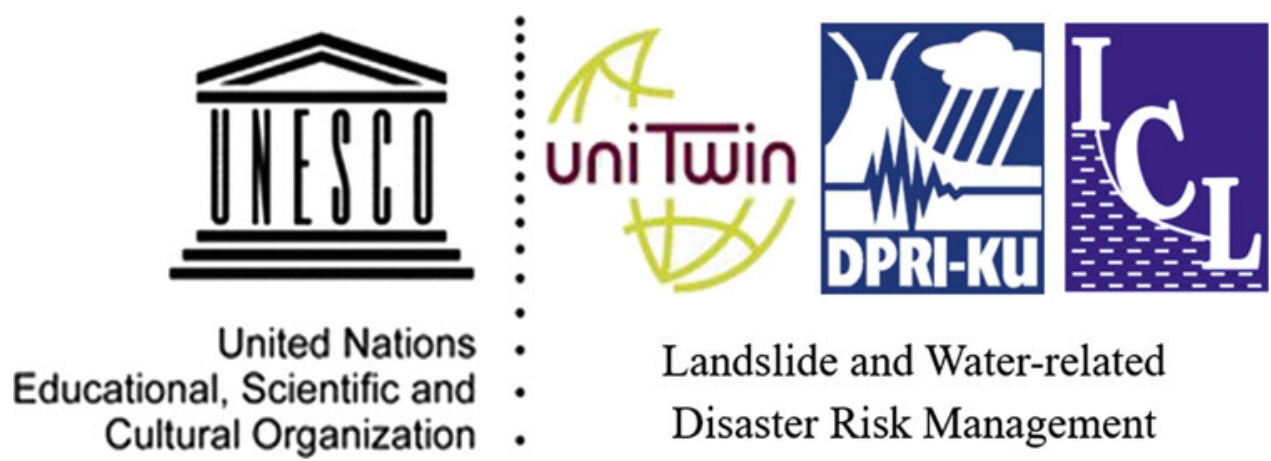




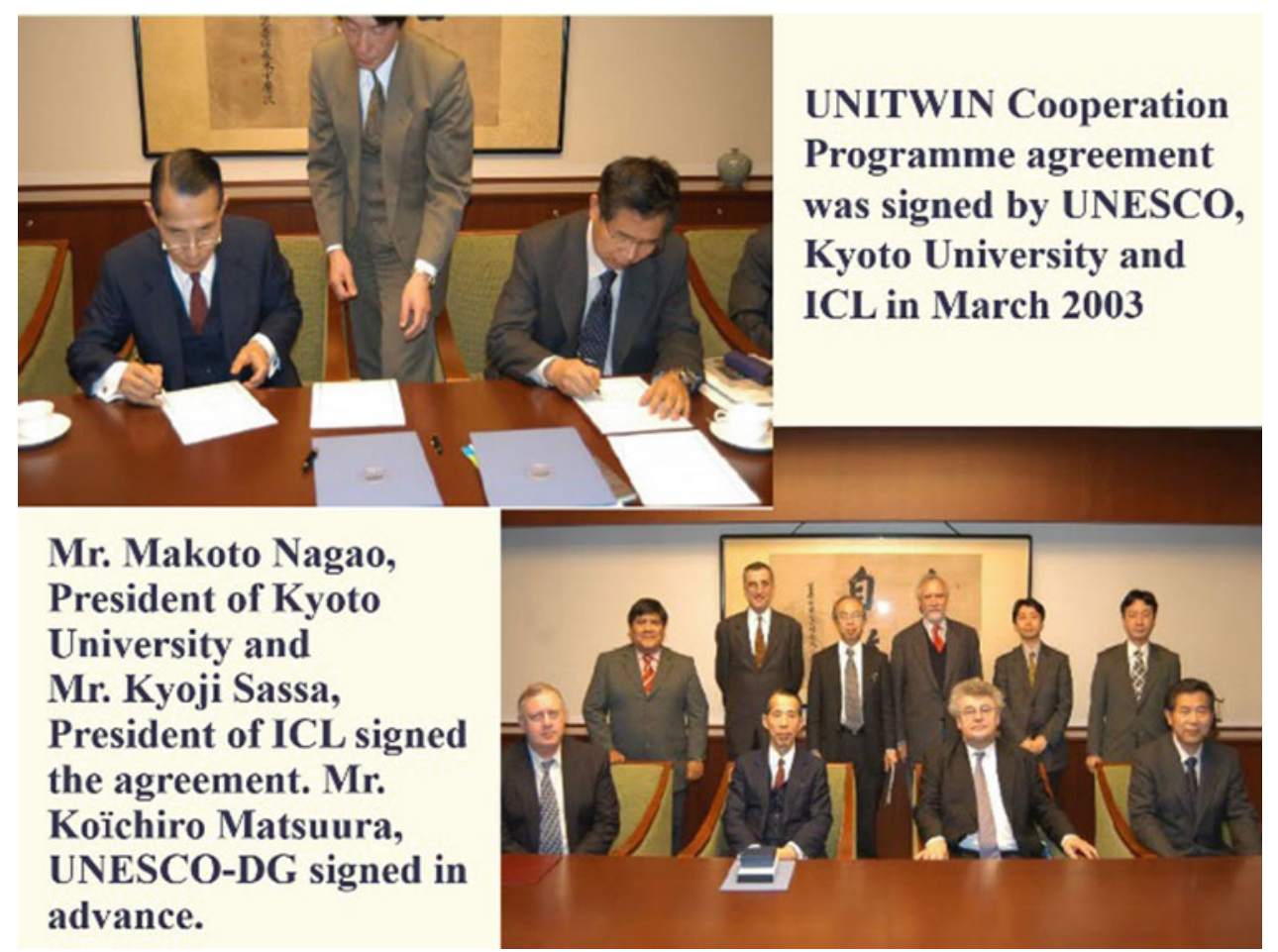

Fig. 2 Signing at the office of Kyoto University President

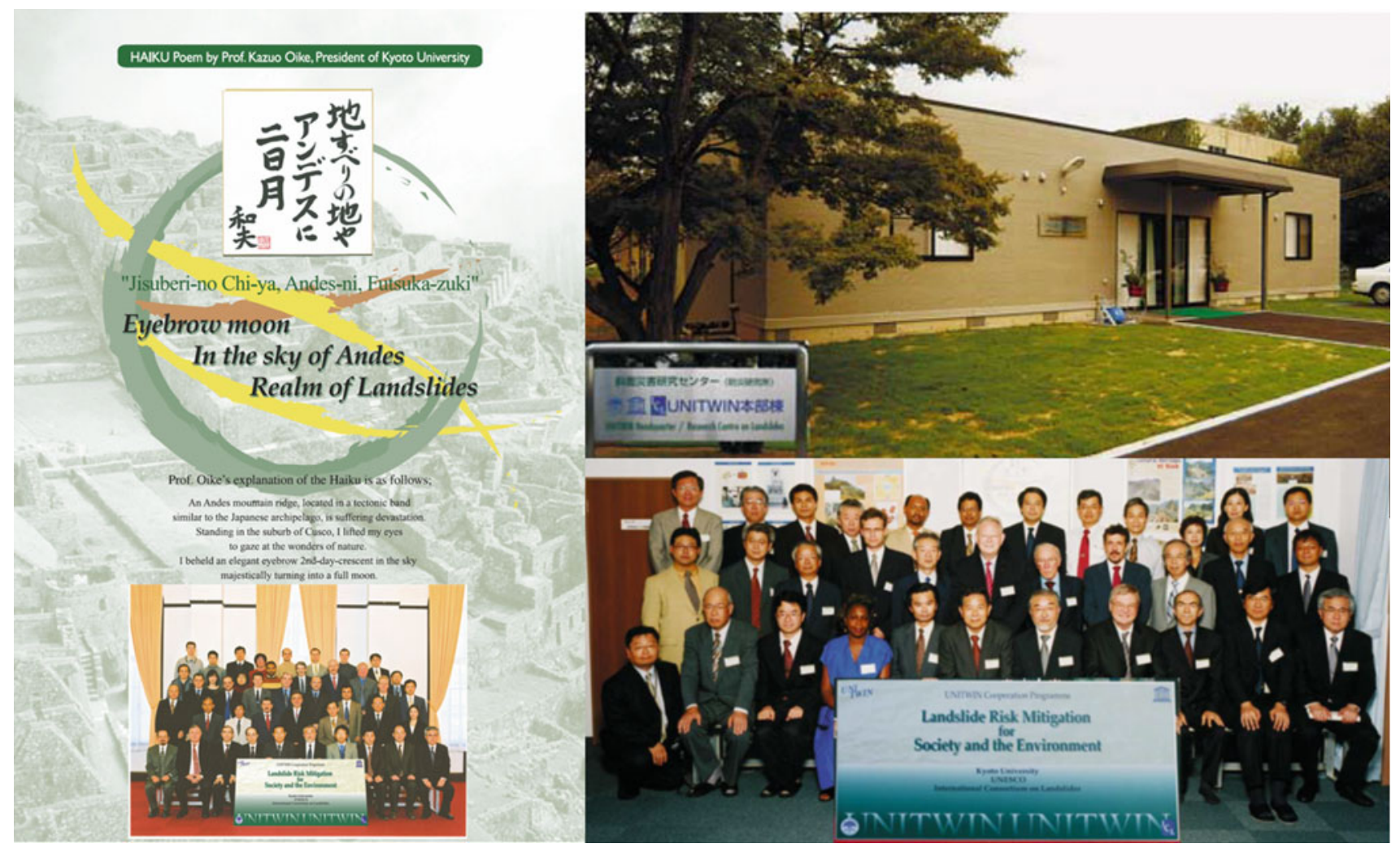

Fig. 3 UNITWIN headquarters building constructed in Uji Campus, Kyoto University in 2004 
ICL has exchanged MoUs with UNESCO, WMO, FAO, UN/ISDR, UNU, ICSU, WEFO to promote the 2006Tokyo Action Plan

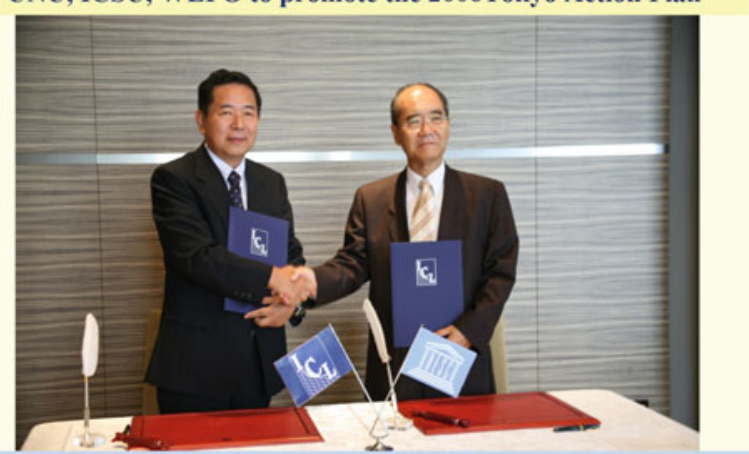

Mr. Koïchiro Matsuura (UNESCO Director General) and Mr. Kyoji Sassa (ICL President) exchanging MoU, 22 August 2006 in Tokyo. Vice President of KU (S. Nishimura) attended the signing ceremony.

Fig. 4 Signing ceremony between UNESCO and ICL in Tokyo on 22 August 2006

implementation of the IPL to formulate a framework for cooperation and to identify focus areas for reducing landslide disaster risk worldwide. It was further agreed that the 2006 Tokyo Action Plan would be implemented within the scope of the Hyogo Framework for Action (HFA) 20052015, "Building the Resilience of Nations and Communities to Disasters", adopted at the United Nations World Conference on Disaster Reduction held in Kobe, Hyogo, Japan in January 2005.

The ICL exchanged Memorandums of Understanding (MoUs) with a number of international organizations, such as UNESCO, WMO, FAO, UNISDR, UNU, ICSU and WFEO, to promote the 2006 Tokyo Action Plan. Figure 4 shows a snapshot at the signing ceremony between $\mathrm{Mr}$. Koïchiro Matsuura, the Director-General of UNESCO, and Mr. Kyoji Sassa, the President of ICL. The UNESCO-KU-ICL UNITWIN Cooperation Programme has strengthened its cooperation. Based on such activities, the ICL organized the First World Landslide Forum in Tokyo on 18-21 November 2008, of which its objectives were:

(1) Promotion of research and exchange of experience through open Forums, Symposia and Workshops;

(2) Advances and achievements of IPL; and

(3) Designation of World Centres of Excellence on Landslide Risk Reduction.

This World Landslide Forum (WLF) was succeeded by the Second WLF in Rome in 2011 and the Third WLF in Beijing in 2014. The Fourth WLF will be held in the Cultural and Congress Centre in Ljubljana, Slovenia in 2017. The Fifth WLF is currently planned to assemble at the International Conference Center, Kyoto on 2-6 November 2020.

\section{The Second Phase of the UNESCO-KU-ICL UNITWIN Cooperation Programme}

In 2010, the UNESCO-KU-ICL UNITWIN Cooperation Programme was extended from its original research area "Landslide Risk Mitigation" to "Landslide and Water-Related Disaster Risk Management" to include more participants dealing with rainfall-induced landslides on slopes, as well as flood, sediment and debris flows in river systems. UNESCO, Kyoto University and ICL renewed the MoU for the UNITWIN programme as an Amendment to the Agreement, which was made on 18 March 2003, at the UNESCO Headquarters in Paris on 16 November 2010. Figure 5 shows the signing by Mr. Paolo Canuti (ICL President), Ms. Sonia Bahri (UNESCO Higher Education Division) and Mr. Norio Okada (Kyoto University DPRI Director) with witnesses: Mr. Kyoji Sassa (ICL Former President), Mr. Badaoui Roubhan (UNESCO Disaster Management Section) and Mr. Salvano Briceno (UNISDR Director-General).

In this second phase, Prof. Kaoru Takara has been playing an important role in capacity building. As show in Table 1, he introduced many international scientists and graduate students to his laboratory at the Disaster Prevention Research Institute (DPRI), Uji Campus Kyoto University. During 2010-2016, he produced eighteen Ph.D.s from nine countries (Brazil 2, China 4, Croatia 2, India, Indonesia 2, Japan 3, Laos PDR, Malaysia 2, Vietnam) at the Graduate School of Engineering, Kyoto University, in which Prof. Takara also has a position as professor in the Civil and Earth Resources Engineering Department of the graduate school.

\section{International Journal "Landslides"}

One of the most important activities of this UNITWIN Cooperation Programme is the publication of an international journal. In cooperation with Springer, a world-renowned publisher, in 2004 the ICL started a journal "Landslides" in full color.

The Springer home page (http://link.springer.com/journal/ 10346) introduces this journal as follows.

As catastrophic events, landslides can cause human injury, loss of life and economic devastation, and destroy construction works and cultural and natural heritage. The journal Landslides is the common platform for publication of integrated research on all aspects of landslides. The journal publishes research papers, news of recent landslide events and information on the activities of the International Consortium on Landslides.

Coverage includes landslide dynamics, mechanisms and processes; volcanic, urban, marine and reservoir landslides; related tsunamis and seiches; hazard assessment and mapping; modeling, monitoring, GIS techniques; remedial or preventive 


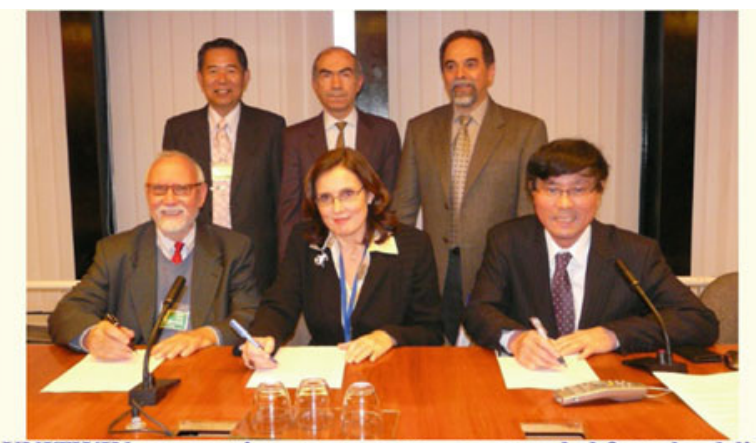

UNITWIN cooperation programme was extended from landslide risk mitigation to landslide and water-related disaster risk management at UNESCO in 2010. Mr. Norio Okada, DPRI Director, Mr. Paolo Canuti and Ms Sonia Bahri, Education Sector of UNESCO signed the Amendment to the Agreement on 18 March 2003.

Fig. 5 Signing ceremony among UNESCO, Kyoto University and ICL in Paris on 16 November 2010

measures; early warning and evacuation and a global landslide database.

Landslides has been accepted at Thompson ISI for coverage in Science Citation Index Expanded, Current Contents/Physical Chemical and Earth Sciences and Current Contents/Engineering Computing and Technology.

The journal already has published 13 volumes (52 issues) since 2004, including 839 articles as of December 2016. Its Impact Factor (IF) is 3.049, which indicates the quality of this journal. In addition to this regular journal, the ICL publishes books at the occasions of the World Landslide Forums as irregular publications, also from Springer. The editorial work on these publications is implemented at the UNITWIN Headquarters Building at the Disaster Prevention Research Institute (DPRI) in Uji Campus, Kyoto University. Further information is reported in the article "Landslides: Journal of International Consortium on Landslides" by Sassa and Arbanas in this volume (Fig. 6).

\section{UNITWIN Laboratory in the Main Campus of Kyoto University, Kyoto Japan}

The UNESCO-KU-ICL UNITWIN Network group proposed two SATREPS (Science and Technology Research Partnership for Sustainable Development) projects, jointly funded by the Japan Science and Technology Agency (JST) and the Japan International Cooperation Agency (JICA). New undrained dynamic-loading ring shear apparatuses (ICL-1 and ICL-2) were developed by these two projects.

1. Risk identification and land-use planning for disaster mitigation of landslides and floods in Croatia (2009-2014) with development of a transportable compact undrained dynamic-loading ring shear apparatus.
2. Development of Landslide Risk Assessment Technology along Transport Arteries in Viet Nam (2011-2017) with development of high-stress undrained dynamic-loading ring shear apparatus to simulate the landslide initiation and the motion of landslides deeper than $100 \mathrm{~m}$.

UNESCO-KU-ICL UNITWIN Project has applied for and accepted the use of one laboratory, UNITWIN Laboratory, since 2011. The two undrained ring shear apparatuses that were developed are installed in this laboratory and invited researchers and students have used these two apparatuses to study landslides.

Figure 7 shows the developed ICL-1 transportable undrained dynamic-loading ring shear apparatus. The counterparts of the Croatia project are three universities in Rijeka, Zagreb and Split, and also the Geological Survey of Croatia. The undrained ring shear apparatus developed in the Disaster Prevention Research Institute, Kyoto University, was difficult to transport because of the difficulty of setting it up for undrained capability, as well as its size and weight. To maintain an undrained condition, the central axis must be completely vertical and shear boxes must be completely horizontal in a single plane. Once the apparatus was moved, reproducing the undrained condition was not easy. It took some months to succeed in maintaining the undrained state during rotation. ICL-1 was designed to be transportable by a SUV car, with no necessity of resetting for the undrained condition.

UNITWIN students and researchers who used this apparatus are:

Maja Ostric (Croatia Water)

School: Graduate School of Engineering, Kyoto University, Japan

Title of Doctoral Dissertation: Development of portable undrained ring shear apparatus and its application

Date of certification: 23 September, 2013

Vivoda Prodan M-Doctor of Philosophy (Ph.D.)

School: Faculty of Civil Engineering, University of Rijeka, Rijeka, Croatia.

Title of Doctoral Dissertation: The influence of weathering process on residual shear strength of fine grained lithological flysch components.

Date of certification: 16 September 2016

Krkač M-Doctor of Philosophy (Ph.D..)

School: Faculty of Mining, Geology and Petroleum Engineering, University of Zagreb, Zagreb, Croatia.

Title of Doctoral Dissertation: A phenomenological model of the Kostanjek landslide movement based on the landslide monitoring parameters.

Date of certification: 17 July 2015 
Table 1 Students and post-doctoral researchers participating in UNITWIN in the period of 2010-2016

\begin{tabular}{|c|c|c|c|c|}
\hline Name & Years & $\begin{array}{l}\text { Status at } \\
\text { UNITWIN }\end{array}$ & Current position & Country \\
\hline Kenichiro Kobayashi & 2009-2013 Ph.D. & P.D. & Assoc. Prof., Kobe U & Japan \\
\hline $\mathrm{He}$ Bin & 2010-2013 & P.D. & Prof., CAS & China \\
\hline Apip & $\begin{array}{l}\text { 2008-2011 Ph.D. } \\
\text { 2011-2013 }\end{array}$ & $\begin{array}{l}\text { Ph.D. student } \\
\text { P.D. }\end{array}$ & Researcher, LIPI & Indonesia \\
\hline Roberto Valmir Da Silva & 2008-2011 Ph.D. & Ph.D. student & Asst. Prof., UFSS & Brazil \\
\hline Tutao Oizumi & 2008-2012 Ph.D. & Ph.D. student & Researcher, JAMSTEC & Japan \\
\hline $\begin{array}{l}\text { Mohd Remy Rozainy bin Mohd } \\
\text { Arif Zainol }\end{array}$ & 2009-2012 Ph.D. & Ph.D. student & Asst. Prof., USM & Malaysia \\
\hline Luo Pigping & $\begin{array}{l}\text { 2009-2012 Ph.D. } \\
\text { 2012-2014 }\end{array}$ & $\begin{array}{l}\text { Ph.D. student } \\
\text { JSPS research } \\
\text { fellow }\end{array}$ & Prof., Changan University & China \\
\hline Pedro Luiz Borges Chaffe & 2009-2012 Ph.D. & Ph.D. student & Asst. Prof., UFSC & Brazil \\
\hline Netrananda Sahu & 2009-2012 Ph.D. & Ph.D. student & Asst. Prof., U. Delhi & India \\
\hline Tomoko Teramoto & 2009-2015 Ph.D. & Ph.D. student & Broad Band Tower & Japan \\
\hline Maja Ostric & 2010-2013 Ph.D. & Ph.D. student & Researcher, Croatia Water & Croatia \\
\hline Shin Young-A & $2011-2013$ & M.Sc. student & Researcher, K-Water & $\begin{array}{l}\text { R. of } \\
\text { Korea }\end{array}$ \\
\hline Kang Eunbi & 2011-2013 & M.Sc. student & & $\begin{array}{l}\text { R. of } \\
\text { Korea }\end{array}$ \\
\hline Nor Eliza binti Alias & 2011-2014 Ph.D. & Ph.D. student & Asst. Prof., UTM & Malaysia \\
\hline Duan Weili & 2011-2014 Ph.D. & Ph.D. student & Asst. Prof., CAS & China \\
\hline Hendy Setiawan & $\begin{array}{l}\text { 2012-2014 } \\
\text { 2014-2017 Ph.D. }\end{array}$ & $\begin{array}{l}\text { M.Sc. student } \\
\text { Ph.D. student }\end{array}$ & Student in Kyoto University & Indonesia \\
\hline Xue Han & $\begin{array}{l}\text { 2012-2014 } \\
\text { 2014-2017 Ph.D. }\end{array}$ & $\begin{array}{l}\text { M.Sc. student } \\
\text { Ph.D. student }\end{array}$ & Student in Kyoto University & China \\
\hline Vilaysane Bounhieng & 2012-2015 Ph.D. & Ph.D. student & Lecturer, National U. Laos & Lao PDR \\
\hline Dang Quang Khang & 2012-2015 Ph.D. & Ph.D. student & Research promotion officer, ICL & Vietnam \\
\hline Josko Troselj & 2012-2016 Ph.D. & Ph.D. student & P.D., Kyoto University & Croatia \\
\hline Hu Maochuan & 2013-2016 Ph.D. & Ph.D. student & P.D., Kyoto University & China \\
\hline Pham Hong Nga & $2012-$ & $\begin{array}{l}\text { JSPS RONPAKU } \\
\text { Fellow }\end{array}$ & $\begin{array}{l}\text { Lecturer, Vietnam Water Resources } \\
\text { University }\end{array}$ & Vietnam \\
\hline Doan Huy Loi & $2013-2015$ & M.Sc. student & $\begin{array}{l}\text { Institute of Transport Science and } \\
\text { Technology, Vietnam }\end{array}$ & Vietnam \\
\hline Pham Van Tien & $\begin{array}{l}2013-2015 \\
2015-\end{array}$ & $\begin{array}{l}\text { M.Sc. student } \\
\text { Ph.D. student }\end{array}$ & Student in Kyoto University & Vietnam \\
\hline Eva Mia Siska & $2014-$ & Ph.D. student & Student in Kyoto University & Indonesia \\
\hline Khai Lin Chong & $2014-$ & Ph.D. student & Student in Kyoto University & Malaysia \\
\hline Karlina & $2015-$ & Ph.D. student & Student in Kyoto University & Indonesia \\
\hline Shi Yongxue & $\begin{array}{l}2014-2016 \\
2016-\end{array}$ & $\begin{array}{l}\text { M.Sc. student } \\
\text { Ph.D. student }\end{array}$ & Student in Kyoto University & China \\
\hline Adnan Artyunov & $\begin{array}{l}2014-2016 \\
2016-\end{array}$ & $\begin{array}{l}\text { M.Sc. student } \\
\text { Ph.D. student }\end{array}$ & Student in Kyoto University & U.S.A. \\
\hline Toma Stoyanov & $2016-$ & Ph.D. student & Student in Kyoto University & Bulgaria \\
\hline Nguyen Duc Ha & $2016-$ & Ph.D. student & Student in Kyoto University & Vietnam \\
\hline Jamila Rajabi & $2016-$ & M.Sc. student & Student in Kyoto University & Afganistan \\
\hline Saima Riaz & $2016-$ & $\begin{array}{l}\text { DPRI Research } \\
\text { Fellow }\end{array}$ & $\begin{array}{l}\text { Asst. Prof., University of Engineering \& } \\
\text { Technology Lahore }\end{array}$ & Pakistan \\
\hline
\end{tabular}


Fig. 6 Cover pages of the journal "Landslides" and an ICL book for the WLF
ICL founded the full-color Journal Landslides since 2004. ICL published the full-color books with the same concept at each WLF.
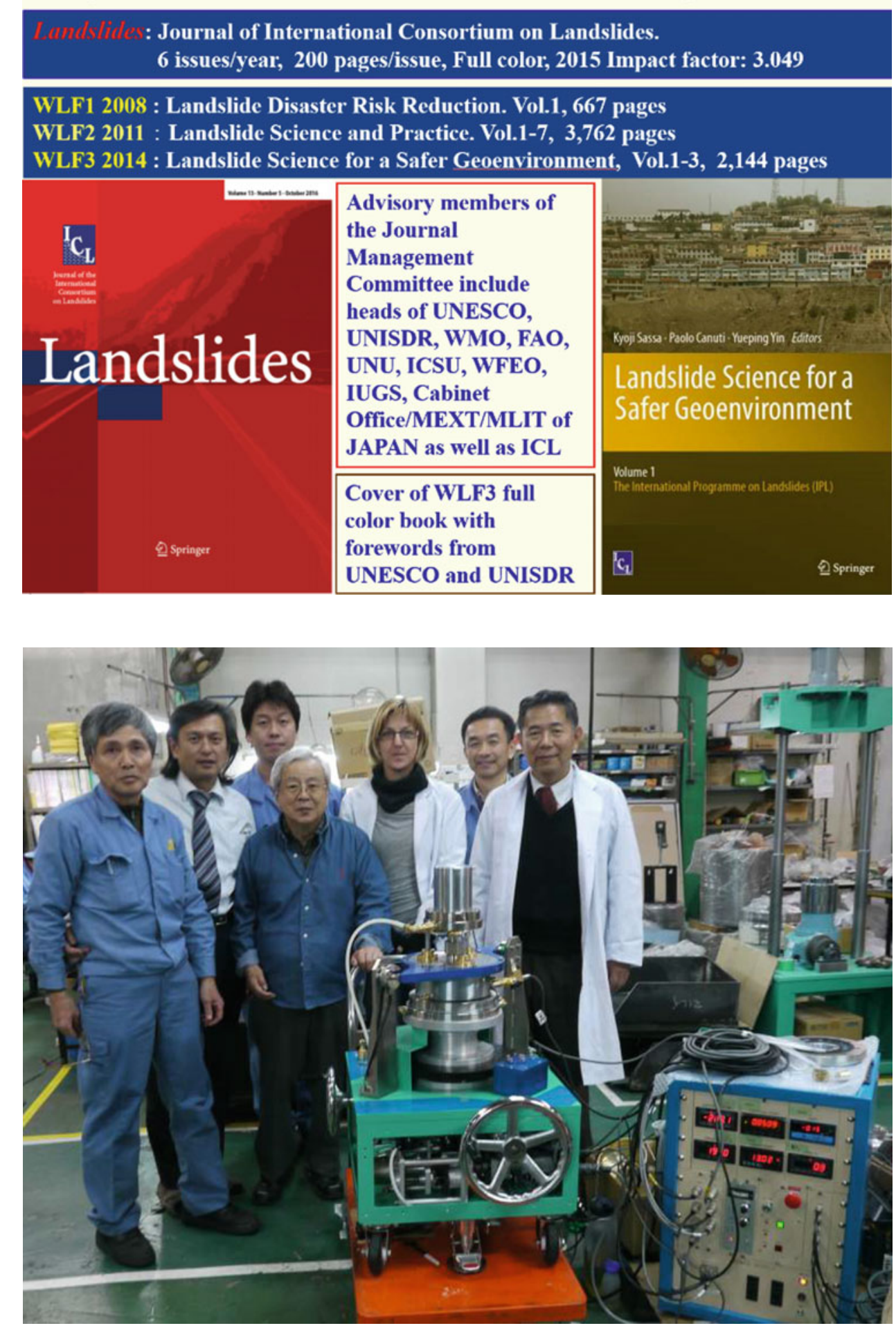

Journal of International Consortium on Landslides.

6 issues/year, 200 pages/issue, Full color, 2015 Impact factor: 3.049
Fig. 7 Photo of developed transportable undrained dynamic-loading ring shear apparatus in the factory of the producing company. (At the center front is late Takeshi Nakasono, chief designer of the apparatus, at the center in the back is Maja Ostric, invited from Croatia, who obtained her Ph.D. based on the development of this apparatus)
Figure 8 shows the developed ICL-2 "High-stress undrained dynamic-loading ring shear apparatus" in use in the UNITWIN Laboratory. A new student who passed the Japanese Government Scholarships examination in the
Japanese Embassy in Hanoi started his doctoral course study from 1st October 2016. ICL-2 was very much modified and developed to avoid trouble and damage to the apparatus by miss-handling, because severe damage occurred to break the 
Fig. 8 ICL-2 High-stress undrained dynamic-loading ring shear apparatus (3 MPa) in the UNITWIN laboratory, Kyoto University

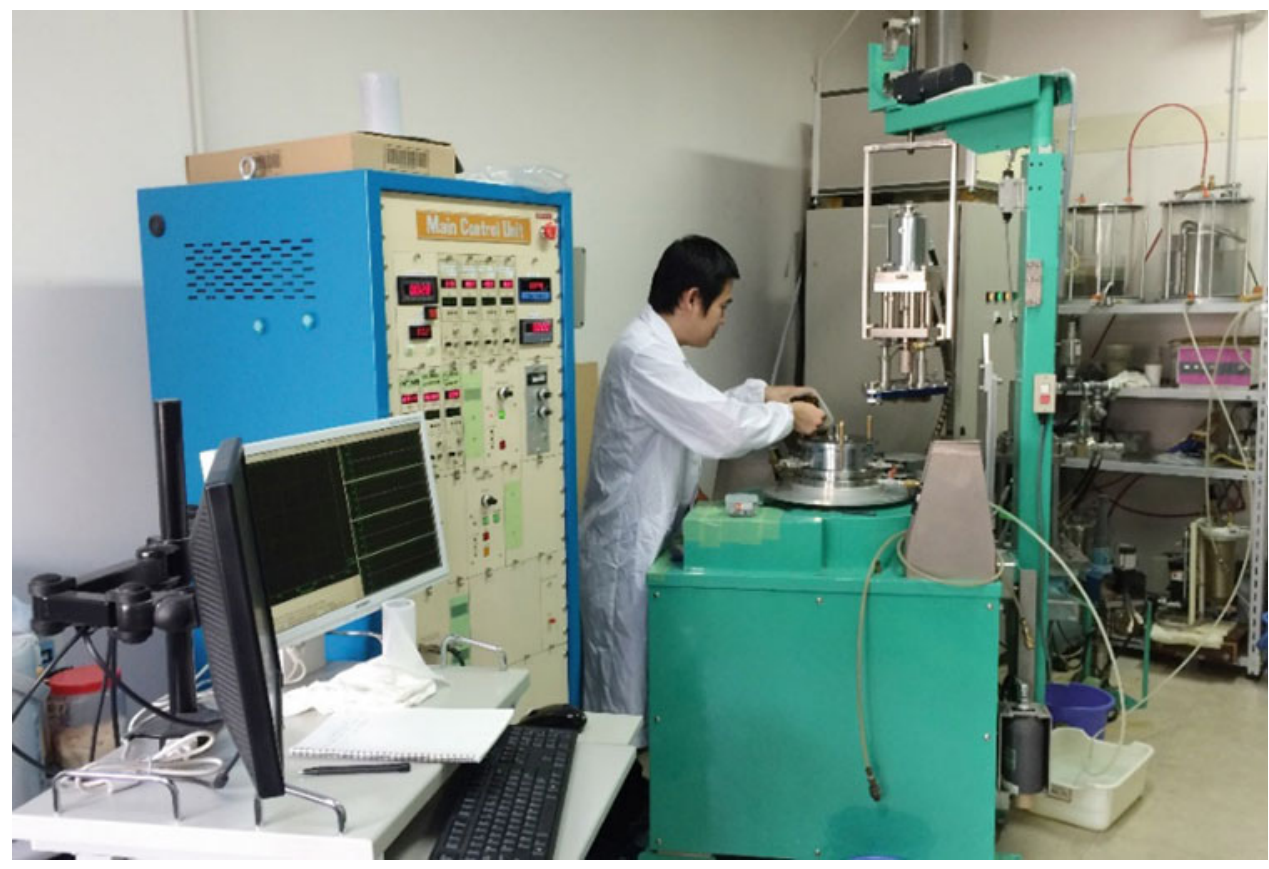

central axis of 3 tons under high-stress testing by the servo-control systems for normal stress, shear stress and gap control during the training.

The apparatus was designed for use in developing countries that need equipment with low maintenance costs and technology. The apparatus was donated to the Institute of Transport Science and Technology of the Ministry of Transport in Vietnam (ITST). ITST has made a very good video manual for ICL-2. Many engineers, even without training in Japan, can handle this complicated apparatus. In September 2016, two researchers were invited to write doctoral papers for a Ph.D. During the discussion, they noted that further testing was needed. They asked engineers in ITST in Hanoi to test samples in the fully saturated state. Then, they conducted the undrained dynamic-loading ring shear test by remote control through the internet. It means that the apparatus of ICL-2 can be used from anywhere in the world, if users know how to test though the UNESCO-KU-ICL UNITWIN network.

UNITWIN students and researchers who have used and currently using this apparatus are:

Dang Quang Khang-Doctor of Philosophy (Ph.D.) School: Graduate School of Engineering, Kyoto University, Japan

Title of Doctoral Dissertation: Development of a new high-stress dynamic-loading ring-shear apparatus and its application to large-scale landslides

Date of certification: 23 September, 2015
Hendy Setiawan

School: Graduate School of Engineering, Kyoto University, Japan

Title of Doctoral Dissertation: Landslide Hazard Assessment on the Upstream of Dam Reservoir

Date of certification: The doctoral thesis has been submitted in December 2016, and is under examination.

Pham Van Tien (ITST, Vietnam) and Nguyen Duc Ha (VIGMR, Vietnam) are currently studying using the ICL-2 and ICL-1 to obtain Ph.D. degrees in the Graduate School of Engineering, Kyoto University, Japan

Lam Huu Quang (ITST, Vietnam) is testing soils taken from Vietnam in the ICL-2 that was donated from Japan to Vietnam. He studied and supervised in the UNTWIN programme in Japan and in Vietnam.

Recent papers published or submitted to the journal Landslides using ICL-2 apparatus include the following.

1. Sassa K, Dang K, He B, Takara K, Inoue K, Nagai O (2014) A new high-stress undrained ring-shear apparatus and its application to the 1792 Unzen-Mayuyama megaslide in Japan. Landslides 11(5):827-842.

2. Sassa K, Dang K, Yanagisawa H, He B (2016) A new landslide-induced tsunami simulation model and its application to the 1792 Unzen-Mayuyama landslide-andtsunami disaster. Landslides 13(6):1405-1419

3. Dang K, Sassa K, Fukuoka H, Sakai N, Sato Y, Takara K, Lam HQ, Doan HL, Pham VT, Nguyen DH 
(2016) Mechanism of two rapid and long runout landslides in the 16 April 2016 Kumamoto earthquake using a ring-shear apparatus and computer simulation (LS-RAPID). Landslides 13(6):1525-1534

4. Lam HQ, Doan HL, Sassa K, Takara K, Dang K, Abe S, Asano S (2016) Risk Assessment of a Precursor Stage of Landslide Threatening the Haivan Railway Station in Vietnam (Submitted to Landslides, under revision).

5. Doan HL, Lam HQ, Sassa K, Takara K, Dang D, Nguyen KT, Pham VT (2016) The 28 July 2015 rapid landslide at Ha Long city, Quang Ninh, Vietnam (Submitted to Landslides).

\section{Acknowledgements and Call for Cooperation}

The UNESCO-KU-ICL UNITWIN Cooperation programme was established at the suggestion, from six participants from the Science Sector and Cultural Sector of UNESCO at the ICL foundation meeting in January 2002, that the International Programme on Landslides (IPL), to be created by the International Consortium on Landslides (ICL), should be authorized by one of UNESCO programmes, and the UNITWIN Cooperation Programme is the best programme to support IPL. Because of this suggestion, Kyoto University and the International Consortium submitted the application form of UNITWIN Cooperation Programme to the UNITWIN/UNESCO Chair Programmes of the Education Sector of UNESCO. Thereafter, the UNESCO-KU-ICL UNTWIN Cooperation Programme obtained support from the Section of Higher Education in the Education Sector of UNESCO, as well as all of ICL member organizations.

Two new UNESCO Chairs were established within this UNITWIN Network in 2016:

- Prevention and Mitigation of Geo-hydrological Hazards at the University of Florence, Italy.

- UNESCO Chair for Water-Related Disaster Risk Reduction at the University of Ljubljana, Slovenia.

These two universities, which have hosted these UNESCO Chair programmes, are active ICL member organizations. We extend our sincere appreciation to all the involved organizations and individuals and wish the successful further development of this network with strong cooperation from all those partners.
Open Access This chapter is licensed under the terms of the Creative Commons Attribution 4.0 International License (http:// creativecommons.org/licenses/by/4.0/), which permits use, sharing, adaptation, distribution and reproduction in any medium or format, as long as you give appropriate credit to the original author(s) and the source, provide a link to the Creative Commons license and indicate if changes were made.
The images or other third party material in this chapter are included in the chapter's Creative Commons license, unless indicated otherwise in a credit line to the material. If material is not included in the chapter's Creative Commons license and your intended use is not permitted by statutory regulation or exceeds the permitted use, you will need to obtain permission directly from the copyright holder. 